University of Nebraska - Lincoln

DigitalCommons@University of Nebraska - Lincoln

Roman L. Hruska U.S. Meat Animal Research

U.S. Department of Agriculture: Agricultural Center

Research Service, Lincoln, Nebraska

2001

\title{
Effect of Extraction Buffer on Estimating Calpain and Calpastatin Activity in Postmortem Ovine Muscle
}

\author{
E. Veiseth \\ Agricultural University of Norway (NLH) \\ M. Koohmaraie \\ USDA-ARS, koohmaraie@email.marc.usda.gov
}

Follow this and additional works at: https://digitalcommons.unl.edu/hruskareports

Veiseth, E. and Koohmaraie, M., "Effect of Extraction Buffer on Estimating Calpain and Calpastatin Activity in Postmortem Ovine Muscle" (2001). Roman L. Hruska U.S. Meat Animal Research Center. 258.

https://digitalcommons.unl.edu/hruskareports/258

This Article is brought to you for free and open access by the U.S. Department of Agriculture: Agricultural Research Service, Lincoln, Nebraska at DigitalCommons@University of Nebraska - Lincoln. It has been accepted for inclusion in Roman L. Hruska U.S. Meat Animal Research Center by an authorized administrator of DigitalCommons@University of Nebraska - Lincoln. 


\title{
Effect of extraction buffer on estimating calpain and calpastatin activity in postmortem ovine muscle
}

\author{
E. Veiseth ${ }^{\mathrm{a}}$, M. Koohmaraie ${ }^{\mathrm{b}, *}$ \\ ${ }^{a}$ Agricultural University of Norway, Department of Food Science, PO Box 5036, 1432 Aas, Norway \\ ${ }^{\mathrm{b}}$ Roman L. Hruska US Meat Animal Research Center, ARS, USDA, Clay Center, NE 68933-0166, USA
}

Received 12 May 2000; received in revised form 18 August 2000; accepted 18 August 2000

\begin{abstract}
The effect of extraction buffer on extractable calpain and calpastatin activity in postmortem muscles was examined. Muscles were removed from ovine carcasses $24 \mathrm{~h}$ after slaughter and extracted with three volumes of two extraction buffers containing 20 (pH 7.5) and $100(\mathrm{pH} 8.3) \mathrm{mM}$ Tris. There was a significant difference in $\mathrm{pH}$ of the muscle homogenates, having a $\mathrm{pH}$ of 5.84 and 7.58 for 20 and $100 \mathrm{mM}$ Tris base, respectively. Calpastatin, $\mu$-calpain and m-calpain all had significantly reduced activity in extracts made with $20 \mathrm{mM}$ Tris ( $\mathrm{pH} 7.5$ ) buffer compared to $100 \mathrm{mM}$ Tris (pH 8.3) buffer, showing a loss of, respectively, 30,57 and $37 \%$. These results indicate the impact of choice of buffer on the extractable calpains and calpastatin activity from postmortem muscle. To avoid loss of calpains due to isoelectric precipitation, the $\mathrm{pH}$ of the muscle homogenate (after homogenization and prior to the first centrifugation) must be above 6.2. Published by Elsevier Science Ltd.
\end{abstract}

Keywords: Calpain; Calpastatin; Muscle; $\mathrm{pH}$

\section{Introduction}

Tenderness is the most important factor related to consumers' acceptability of meat, and it is known to improve during postmortem storage. This improvement has been found to arise from proteolysis of key myofibrillar proteins and other associated proteins, and it is believed that the calpain system is the main system responsible for this proteolysis (for review see Koohmaraie, 1992, 1996). Due to the significance of postmortem proteolysis and the role that calpain plays in this process, calpains have been a subject of intense research in meat science during the last two decades. Because calpains and their inhibitor, calpastatin, are localized in the cytoplasm of muscle cells, they can be extracted from the muscle tissue by homogenization and

\footnotetext{
\ention of a trade name, proprietary product or specific equipment is necessary to report factually on the availability data; however, the USDA neither guarantees nor warrants the standard of the product, and the use of the name by the USDA implies no approval of the product to the exclusion of others that may also be suitable.

* Corresponding author. Tel.: + 1-402-762-4221; fax: + 1-402-7624149 .

E-mail address: koohmaraie@email.marc.usda.gov (M. Koohmaraie).
}

centrifugation. Some proteins, such as the calpains, will start to precipitate when the $\mathrm{pH}$ approaches their isoelectric point (pI). The $\mathrm{pI}$ of $\mu$-calpain is between 5.3 and 5.5, while m-calpain has a pI between 4.6 and 4.9 (Suzuki, Kawashima \& Imahori, 1984; Yoshimura, Kikuchi, Sasaki, Kitahara, Hatanaka \& Murachi, 1983). To prevent loss of calpains during extraction, it is important that the homogenate $\mathrm{pH}$ is kept well above their $\mathrm{pI}$. The calpastatin pI varies from 4.55 in human erythrocytes (Takano \& Murachi, 1982) to 4.85-4.95 in bovine cardiac muscle (Otsuka \& Goll, 1987), but unlike the calpains, calpastatin does not precipitate at its pI (Goll, Kleese, Okitani, Kumamoto, Cong \& Kapprell, 1990).

Different groups have used different buffers and extraction volumes to study the calpain system in postmortem muscle. The results indicate that both $\mu$-calpain and calpastatin activity decline rapidly during postmortem storage, $\mu$-calpain more extensively than calpastatin, while m-calpain activity is stable (Ducastaing, Valin, Schollmeyer \& Cross, 1985; Geesink \& Koohmaraie, 1999; Koohmaraie, Seideman, Schollmeyer, Dutson \& Crouse, 1987; Kretchmar, Hathaway, Epley \& Dayton, 1990; Vidalence, Cottin, Merdaci \& Ducastaing, 1983). There seems to be an agreement with regard to effect of postmortem storage on $\mu$-calpain and calpastatin but not 
for the effect of postmortem storage on m-calpain. Some studies have indicated that m-calpain also loses its activity during postmortem storage (Beltran, Jaime, Santolaria, Sanudo, Alberti \& Roncales, 1997; Sensky, Parr, Bardsley \& Buttery, 1996; Sensky et al., 1999). However, with the exception of calcium chloride infusion of carcasses or calcium chloride injection of cuts of meat, we have failed to observe any change in the activity of m-calpain (for review see Koohmaraie, 1996). Even after 56 days of postmortem storage, ovine muscle had m-calpain activity similar to that of at-death muscle (Geesink \& Koohmaraie, 1999).

We hypothesized that the discrepancy regarding the effect of postmortem storage on m-calpain activity is caused by use of different extraction buffers. Hence, the objective of this study was to examine the effect of extraction buffer on extractable calpain and calpastatin activity in postmortem muscles.

\section{Materials and methods}

\subsection{Experiment 1}

Two market weight lambs were slaughtered and carcasses stored at $4^{\circ} \mathrm{C}$. At $24 \mathrm{~h}$ postmortem Biceps femoris, Semimembranosus and Semitendinosus were removed from one side of both carcasses. Each muscle was trimmed of visible fat and connective tissue, minced and mixed well before $2 \times 25$ g samples were taken for extraction of calpain and calpastatin.

Two different extraction buffers were used, the standard buffer in our laboratory and the buffer used in the studies that reported loss of $\mathrm{m}$-calpain activity in postmortem muscle. The buffers were: buffer A (100 mM Tris base, $10 \mathrm{mM}$ EDTA, $0.05 \%$ 2-mercaptoethanol [MCE], adjusted with $\mathrm{HCl}$ to $\mathrm{pH} 8.3)$ and buffer $\mathrm{B}(20 \mathrm{mM}$ Tris base, $10 \mathrm{mM}$ EDTA, $0.05 \% \mathrm{MCE}$, adjusted with $\mathrm{HCl}$ to $\mathrm{pH}$ 7.5). Inhibitors were added to both buffers just before homogenization ( $2 \mathrm{mM}$ phenylmethylsulfonyl fluoride, $100 \mathrm{mg} / 1$ ovomucoid and $16 \mathrm{mg} / 1$ leupeptin). Minced tissue was homogenized in 3 vol. of extraction buffer A or B, using a Waring blender three times on high speed for $30 \mathrm{~s}$, with a $30 \mathrm{~s}$ cooling period between bursts. The homogenate was centrifuged at $28,000 \times \boldsymbol{g}_{\max }$ for $2 \mathrm{~h}$, and the $\mathrm{pH}$ of the supernatant was measured before it was dialyzed overnight against dialysis buffer (40 mM Tris base, $5 \mathrm{mM}$ EDTA, 0.05\% MCE, pH 7.35). After dialysis the extracts were clarified by centrifugation at $28,000 \times g_{\max }$ for $1 \mathrm{~h}$ and filtered over glass wool before the $\mathrm{pH}$ was measured again.

The extracts were loaded on $1.5 \times 20 \mathrm{~cm}$ columns of DEAE-Sephacel (Pharmacia LKB Biotechnology, Uppsala, Sweden) by gravity. After loading, columns were washed with elution buffer $(40 \mathrm{mM}$ Tris base, 0.5 $\mathrm{mM}$ EDTA, $0.05 \%$ MCE, pH 7.35) until the outflow had an $\mathrm{A}_{278}<0.1$. Bound proteins were eluted using a linear gradient from 25 to $400 \mathrm{mM} \mathrm{NaCl}$ in elution buffer $(250 \mathrm{~mL}$ of each) at $30 \mathrm{ml} / \mathrm{h}$, collecting $140 \mathrm{frac}$ tions of $3 \mathrm{ml}$ each. Calpain and calpastatin activities were determined as described by Koohmaraie (1990).

\subsection{Experiment 2}

Four market weight lambs were slaughtered and carcasses stored at $4^{\circ} \mathrm{C}$. At 24 (two carcasses) and 48 (two carcasses) hrs postmortem, the semimembranosus was removed. The $\mathrm{pH}$ of the muscles was measured using an ARGUS $\chi$ with a red-line LanceFET probe (SENTRON Inc., Gig Harbor, WA) pH meter. Each muscle was trimmed of visible fat and connective tissues, minced and mixed before $8 \times 5 \mathrm{~g}$ were taken for homogenization. The muscle samples were homogenized in two different buffers containing 20 and $50 \mathrm{mM}$ Tris base with a $\mathrm{pH}$ of 7.5 and 8.3 , respectively. The tissue was homogenized in $3,6,8$ and 10 vol. of buffer using a Polytron (3 vol.) or a Waring blender three times on high speed for $30 \mathrm{~s}$, with a $30 \mathrm{~s}$ cooling period interspersed between bursts. The homogenate was centrifuged at $28,000 \times \boldsymbol{g}_{\max }$ for $1 \mathrm{~h}$ and filtered over glass wool before the $\mathrm{pH}$ was measured.

\subsection{Statistical analysis}

All data in experiment 1 were analyzed as a split-plot where samples were the whole-plot and buffer was the split-plot. Each muscle was treated as an independent observation. Muscle and animal differences were not the objective of this study. Different animals and muscles were utilized to test the buffer effect.

For experiment 2, data were analyzed as a factorially arranged split-plot where animals were the whole-plot and buffer and volume were factorially arranged within each animal. Least-squares means were separated using the PDIFF procedure of SAS (1988).

\section{Results}

\subsection{Effect of buffer on extracted calpain and calpastatin activity}

Since the $\mathrm{pH}$ of the homogenate does not differ from the $\mathrm{pH}$ of the supernatant after centrifugation (data not shown), the supernatant $\mathrm{pH}$ will hereafter be referred to as homogenate $\mathrm{pH}$. Extraction with buffer $\mathrm{B}$ gave a lower $(P<0.05) \mathrm{pH}$ of the homogenate $(5.84)$ than extraction with buffer A (7.58; Table 1). There was no difference $(P>0.05)$ in $\mathrm{pH}$ after dialysis. For both calpains and calpastatin the activity was reduced $(P<0.05)$ when extraction was done with buffer $\mathrm{B}$ compared to buffer $\mathrm{A}$, and the activities of $\mu$-calpain, m-calpain and calpastatin were 57, 37 and 30\% lower, respectively. 
Table 1

Calpain and calpastatin activity, and $\mathrm{pH}$ after extraction of ovine muscle with 3 volumes of two buffers at 24 h postmortem $(n=5)$

\begin{tabular}{llllll}
\hline & Buffer A $^{\mathrm{a}}$ & Buffer B $^{\mathrm{b}}$ & S.E. $^{\mathrm{c}}$ & \% Loss & $\mathrm{P}<\mathrm{F}$ \\
\hline $\mathrm{pH}_{\text {homogenate }}$ & 7.58 & 5.84 & 0.03 & & 0.001 \\
pH $_{\text {after dialysis }}$ & 7.42 & 7.42 & 0.02 & & 0.899 \\
Calpastatin $^{\mathrm{d}}$ & 2.47 & 1.74 & 0.13 & 30 & 0.018 \\
$\mu_{\text {-calpain }}{ }^{\mathrm{d}}$ & 0.39 & 0.17 & 0.01 & 57 & 0.001 \\
m-calpain $^{\mathrm{d}}$ & 0.95 & 0.60 & 0.03 & 37 & 0.002 \\
\hline
\end{tabular}

a $100 \mathrm{mM}$ Tris base, $\mathrm{pH} 8.3$.

b $20 \mathrm{mM}$ Tris base, $\mathrm{pH} 7.5$.

c Standard errors.

d Activity given as units/g muscle.

\subsection{Effect of buffer and extraction volume on homogenate $\mathrm{pH}$}

All homogenates extracted with $50 \mathrm{mM}$ Tris- $\mathrm{HCl}, \mathrm{pH}$ 8.3 buffer had a $\mathrm{pH}$ above 6.6 , while none of the homogenates extracted with $20 \mathrm{mM}$ Tris- $\mathrm{HCl}, \mathrm{pH} 7.5$ buffer had a $\mathrm{pH}$ above 6.6 (Fig. 1). There was a significant $(P<0.05)$ difference in $\mathrm{pH}$ between the two buffers at all different extraction volumes used, and for both buffers, the $\mathrm{pH}$ increased significantly $(P<0.05)$ as extraction volume was increased. As shown in Fig. 1, the only combinations of buffer and volume that were not significantly different in $\mathrm{pH}$ of the homogenates were 3 vol. of $50 \mathrm{mM}$ and 10 vol. of $20 \mathrm{mM}$ Tris base.

\section{Discussion}

The initial method to isolate m-calpain from rabbit skeletal muscle used isoelectric precipitation between
pH 4.9 and 6.2 (Busch, Stromer, Goll \& Suzuki, 1972). This means that it is crucial to keep the homogenate $\mathrm{pH}$ well above 6.2 to avoid precipitation of m-calpain during subsequent centrifugation. Since $\mu$-calpain has an isoelectric point similar to that of m-calpain (Suzuki et al., 1984; Yoshimura et al., 1983), the consequence of a homogenate $\mathrm{pH}$ below 6.2 would be similar for both calpains. Our results show that extraction with buffer B gave a $\mathrm{pH}$ low enough for calpains to start precipitating (as determined by the reduced extractable calpain activity). Thus, there was a significant loss in extractable calpain activity with buffer B as compared to buffer A. Unlike calpains, calpastatin does not precipitate at its $\mathrm{pI}$ (Goll et al., 1990), and, therefore, we did not expect a difference between buffers for the calpastatin activity. Surprisingly, we found a significant reduction in calpastatin activity with buffer B. Because there was no significant difference in $\mathrm{pH}$ of the supernatant after dialysis, the conditions during ion-exchange chromatography and activity assays would be the same for all samples. This implies that the differences found in activities must be related to the homogenate $\mathrm{pH}$.

Based on these results, it is clear that use of different extraction buffers and volumes will have a great effect on extractable calpain and calpastatin activity, and this may be the reason why different groups have found contradictory results for m-calpain activity in postmortem muscles. Several groups have reported that $\mu$ calpain and calpastatin activities decline fairly rapidly during postmortem storage, and that m-calpain retains its activity. These groups adjusted the $\mathrm{pH}$ of the homogenate before centrifugation (Ducastaing et al., 1985; Vidalenc et al., 1983) or used an extraction buffer with increased buffering capacity (Kretchmar et al., 1990), and would, therefore, not experience a loss of

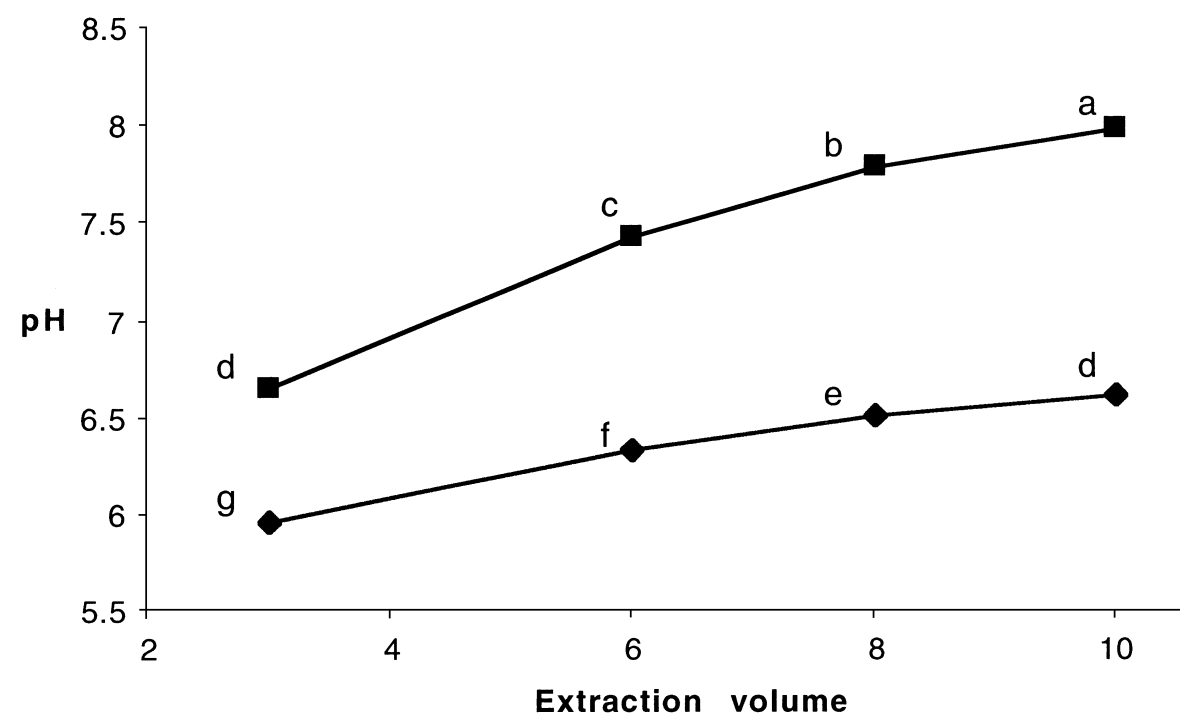

Fig. 1. Changes in the $\mathrm{pH}$ of supernatants of ovine muscle ( $\mathrm{n}=2$ at $24 \mathrm{~h}$ and $\mathrm{n}=2$ at $48 \mathrm{~h}$ postmortem) extracted with different buffers and extraction volumes. - $-50 \mathrm{mM}$ Tris base, $\mathrm{pH} 8.3,-\downarrow-20 \mathrm{mM}$ Tris base, $\mathrm{pH}$ 7.5. Mean with different letters are significantly different $(P<0.01)$. SEM $=0.02$. Buffer $\times$ Volume Interaction $(P<0.0001)$. 
activity due to isoelectric precipitation. Geesink and Koohmaraie (1999) reported that the activity of m-calpain remained stable even after 56 days of postmortem storage of lambs. Other groups have shown that m-calpain activity declines during postmortem storage. In a study of the relationship between plasma epinephrine concentration and calpain and calpastatin activity in pork, Sensky et al. (1996) reported a rapid decrease of $\mu$-calpain activity over the first $24 \mathrm{~h}$, and a significant decrease in m-calpain activity between 0 and $192 \mathrm{~h}$ postmortem. They used 3 vol. of $20 \mathrm{mM}$ Tris, $\mathrm{pH} 7.5$, to extract calpain, and reported that the activity of $\mathrm{m}$-calpain decreased by $81 \%$ in control pigs and by $44 \%$ in pigs infused with epinephrine. Interestingly, Sensky et al. (1996) reported that the correlation between $\mathrm{pH}$ at 45 min postmortem and the half-life for reduction in m-calpain activity was highly significant $\left(r^{2}=0.82, P<0.001\right)$. The results presented in this study show that the extraction buffer and volume Sensky et al. (1996) used would not give a $\mathrm{pH}$ high enough to quantitatively extract calpains when the muscle $\mathrm{pH}$ declines postmortem. Our results show that it is necessary to use at least 8 vol. of $20 \mathrm{mM}$ Tris, $\mathrm{pH}$ 7.5, to avoid isoelectric precipitation of calpains (Fig. 1). When extracted at $24 \mathrm{~h}$ postmortem, the decline in $\mu$ calpain activity will be a combined result of a true loss during postmortem storage and isoelectric precipitation, the decline in m-calpain activity will be caused by precipitation alone, and would, therefore, be an artifact of the extraction procedure. In light of the current observations, conclusions by other groups that m-calpain activity declines postmortem should be re-examined. The decline in activity observed by others (Beltran et al., 1997; Sensky et al., 1996, 1999) may be a result of insufficient buffering and not true activity loss.

Sensky et al. (1999) were apparently aware of the potential problem associated with the use of their extraction buffer. They justified their buffer by suggesting that the $\mathrm{pH}$ of postmortem muscle (i.e. 5.4-5.5) lead to partial precipitation or denaturation of calpains in situ. Hence, they indicated that the extraction procedure employed recovers only the residual, soluble activity reflecting the proportion of original activity that is still available to participate in the tenderization process. The argument used by Sensky et al. (1999) may not be true for two reasons. First of all, the fact that we can increase m-calpain recovery by ensuring that the $\mathrm{pH}$ of the homogenate is greater than 6.2, suggests that in situ $\mathrm{pH}$ conditions do not cause denaturation. Secondly, the work of Busch et al. (1972) clearly shows that isoelectric precipitation does not inactivate m-calpain. Nevertheless, we decided to examine the interaction between $\mathrm{pH}$ and ionic strength on isoelectric precipitation of $\mathrm{m}$-calpain. Winger and Pope (1980-1981) reported that the osmotic pressure in postrigor beef muscle was in the range of 480-540 mOs, which was equivalent to a $\mathrm{NaCl}$ concentration of $270-295 \mathrm{mM}$. Based on this, to demonstrate the effect of ionic strength on calpain precipitation, we adjusted the salt concentration of DEAE-Sephacel purified m-calpain to 0,100, and $250 \mathrm{mM} \mathrm{NaCl}$. We then adjusted the $\mathrm{pH}$ to 4.9 (isoelectric precipitation), centrifuged and adjusted the $\mathrm{pH}$ of the supernatant to 7.5, and assayed it for m-calpain activity. By assaying for $\mathrm{m}$-calpain activity before and after isoelectric precipitation, we were able to examine the effect of ionic strength on $\mathrm{pH}$-induced calpain precipitation. At 0,100 , and $250 \mathrm{mM} \mathrm{NaCl}, 55,40$, and $30 \%$ of the m-calpain activity was lost due to precipitation at $\mathrm{pH} 4.9$. These results demonstrate that ionic strength modifies the proportion of calpain that is precipitated at its pI, and imply that calpains probably do not precipitate in postmortem muscle. This suggests that isoelectric precipitation during extraction, rather than in situ conditions, was responsible for the decline in m-calpain activity that Sensky et al. (1999) reported.

These results indicate that it is crucial to keep homogenate $\mathrm{pH}$ above 6.2 (either by using an appropriate combination of buffering capacity and buffer volume or by adjusting the $\mathrm{pH}$ of the muscle homogenate prior to the first centrifugation), for accurate quantification of calpain and calpastatin activity in postmortem muscle.

\section{References}

Beltran, J. A., Jaime, I., Santolaria, P., Sanudo, C., Alberti, P., \& Roncales, P. (1997). Effect of stress-induced high post-mortem $\mathrm{pH}$ on protease activity and tenderness of beef. Meat Science, 45, 201-207.

Busch, W. A., Stromer, M. H., Goll, D. E., \& Suzuki, A. (1972). $\mathrm{Ca}^{2+}$-specific removal of $\mathrm{Z}$ lines from rabbit skeletal muscle. Journal of Cell Biology, 52, 367-381.

Ducastaing, A., Valin, C., Schollmeyer, J., \& Cross, R. (1985). Effects of electrical stimulation on post-mortem changes in the activities of two $\mathrm{Ca}$ dependent neutral proteinases and their inhibitor in beef muscle. Meat Science, 15, 193-202.

Geesink, G. H., \& Koohmaraie, M. (1999). Postmortem proteolysis and calpain/calpastatin activity in callipyge and normal lamb biceps femoris during extended postmortem storage. Journal of Animal Science, 77, 1490-1501.

Goll, D. E., Kleese, W. C., Okitani, A., Kumamoto, T., Cong, J., \& Kapprell, H. P. (1990). Historical background and current status of the $\mathrm{Ca}^{2+}$-dependent proteinase system. In R. L. Mellgren, \& T. Murachi, Intracellular calcium-dependent proteolysis (pp. 3-23). Boca Raton: CRC Press, Inc.

Koohmaraie, M., Seideman, S. C., Schollmeyer, J. E., Dutson, T. R., \& Crouse, J. D. (1987). Effect of post-mortem storage on $\mathrm{Ca}^{++}$. dependent proteases, their inhibitor and myofibril fragmentation. Meat Science, 19, 187-196.

Koohmaraie, M. (1990). Quantification of $\mathrm{Ca}^{2+}$-dependent protease activities by hydrophobic and ion-exchange chromatography. Journal of Animal Science, 68, 659-665.

Koohmaraie, M. (1992). The role of $\mathrm{Ca}^{2+}$-dependent proteases (calpains) in post mortem proteolysis and meat tenderness. Biochimie, 74, 239-245.

Koohmaraie, M. (1996). Biochemical factors regulating the toughening and tenderization processes of meat. Meat Science, 43, 193-201.

Kretchmar, D. H., Hathaway, M. R., Epley, R. J., \& Dayton, W. R. (1990). Alterations in postmortem degradation of myofibrillar proteins in muscle of lambs fed a $\beta$-adrenergic agonist. Journal of Animal Science, 68, 1760-1772. 
Otsuka, Y., \& Goll, D. E. (1987). Purification of the $\mathrm{Ca}^{2+}$-dependent proteinase inhibitor from bovine cardiac muscle and its interaction with the millimolar $\mathrm{Ca}^{2+}$-dependent proteinase. Journal of Biological Chemistry, 262, 5839-5851.

SAS/STAT ${ }^{\circledR}$ User's guide (Release 6.03). Cary, NC: SAS Inst. Inc.

Sensky, P. L., Parr, T., Bardsley, R. G., \& Buttery, P. J. (1996). The relationship between plasma epinephrine concentration and the activity of the calpain enzyme system in porcine longissimus muscle. Journal of Animal Science, 74, 380-387.

Sensky, P. L., Parr, T., Lockley, A. K., Bardsley, R. G., Buttery, P. J., Wood, J. D., \& Warkup, C. (1999). Altered calpain levels in longissimus muscle from normal pigs and heterozygotes with the ryanodine receptor mutation. Journal of Animal Science, 77, 2956-2964.

Suzuki, K., Kawashima, S., \& Imahori, K. (1984). Structure and func- tion of $\mathrm{Ca}^{2+}$-activated protease. In $\mathrm{S}$. Ebashi, , et al., Calcium regulation in biological systems (pp. 213-226). Tokyo: Academic Press.

Takano, E., \& Murachi, T. (1982). Purification and some properties of human erythrocyte calpastatin. Journal of Biochemistry, 92, 2021-2028.

Vidalenc, P., Cottin, P., Merdaci, N., \& Ducastaing, A. (1983). Stability of two $\mathrm{Ca}^{2}$-dependent neutral proteinases and their specific inhibitor during post-mortem storage of rabbit skeletal muscle. Journal of the Science of Food and Agriculture, 34, 1241-1250.

Winger, R. J., \& Pope, C. G. (1980-1981). Osmotic properties of postrigor beef muscle. Meat Science, 5, 355-369.

Yoshimura, N., Kikuchi, T., Sasaki, T., Kitahara, A., Hatanaka, M., \& Murachi, T. (1983). Two distinct $\mathrm{Ca}^{2+}$ proteases (Calpain I and Calpain II) purified concurrently by the same method from rat kidney. Journal of Biological Chemistry, 258, 8883-8889. 